\title{
University libraries: The role of an accessible campus on the inclusion of users with special needs
}

\author{
Bibliotecas universitárias: o papel de um campus acessível \\ na inclusão de usuários com necessidades especiais
}

\author{
Isabel Cristina dos Santos DINIZ1 (iD) 0000-0002-6669-3845 \\ Ana Margarida ALMEIDA² (D) 0000-0002-7349-457X \\ Cassia Cordeiro FURTADO1 1 (D) 0000-0002-3682-1519
}

\begin{abstract}
The purpose of this paper is to present preliminary results of an ongoing research that seeks to diagnose inclusive practices in Brazilian and Portuguese university libraries, particularly in what concerns to the role of an accessible campus on the inclusion of users with special needs. The results were collected through an online questionnaire applied to 87 library directors (54 Brazilian and 33 Portuguese). Fifty valid answers were collected (28 Brazilian and 22 Portuguese).The results allowed to identify accessibility issues, namely in what regards to the access to the campus and to the lack of teams of librarians with specific skills to aid and assist these users. We conclude that many of these libraries are integrated in campuses without accessible infrastructure, and therefore, are not able to promote the inclusion of the students with special needs. Respondents say they are aware of their limitations and weaknesses when facing this challenge and show openness to change their practices and attitudes towards a new future scenario in which they could build solutions to improve the accessibility and inclusion in these libraries.
\end{abstract}

Keywords: Accessibility. Assistive Technologies. Inclusive Library. Special Needs. University Library.

\section{Resumo}

O objetivo deste trabalho é apresentar os resultados preliminares de uma pesquisa em andamento que procura diagnosticar práticas inclusivas em bibliotecas universitárias brasileiras e portuguesas. A pesquisa visa elucidar aspectos relativos ao papel de um campus acessível na inclusão de usuários com necessidades especiais. Os resultados foram coletados por meio de um questionário online aplicado a oitenta e sete diretores de bibliotecas (cinquenta e quatro brasileiros e trinta e três portugueses). Foram coletadas cinquenta respostas válidas (vinte e oito brasileiras e vinte e duas portuguesas). Os resultados permitiram identificar problemas de acessibilidade, nomeadamente no que diz respeito ao acesso ao campus e à falta de equipes de bibliotecários com habilidades específicas para auxi-

\footnotetext{
1 Universidade Federal do Maranhão, Centro de Ciências Humanas e Sociais Aplicadas, Faculdade de Biblioteconomia. Cidade Universitária Dom Delgado, Av. dos Portugueses, 1966, Bacanga, 65080-805, São Luís, MA, Brasil. Correspondência para/Correspondence to: I.C.S. DINIZ. E-mail: <isantosdiniz70@gmail.com>.

2 Universidade de Aveiro, Programa de Pós-Graduação em Ciências e Tecnologias da Comunicação, Departamento de Comunicação e Arte. Aveiro, Portugal.

Support: Fundação de Amparo à Pesquisa e ao Desenvolvimento Científico e Tecnológico do Maranhão (n` BD-02885/15)

Article based on the thesis of I.C.S. DINIZ, entitled "Bibliotecas universitárias inclusivas brasileiras e portuguesas: ações estratégias". Universidade de Aveiro, Portugal, 2018.

Received on March 3, 2018, final version resubmitted on August 28, 2018 and approved on September 10, 2018.
}

Como citar este artigo/How to cite this article

Diniz, I.C.S.; Almeida, A.M.; Furtado, C.C. University libraries: The role of an accessible campus on the inclusion of users with special needs. Transinformação, v.31, e180029, 2019. http://dx.doi.org/10.1590/2318-0889201931e180029 
liar esses usuários. Concluímos que muitas dessas bibliotecas estão integradas em campi sem infra-estrutura acessível e, portanto, que não são capazes de promover a inclusão de estudantes com necessidades especiais. Os respondentes afirmam que estão conscientes de suas limitações e fraquezas quando enfrentam esse desafio. Por isso, mostram abertura para mudar suas práticas e atitudes em relação a um novo cenário futuro no qual eles possam construir soluções para se melhorar a acessibilidade e a inclusão nessas bibliotecas.

Palavras-chave: Acessibilidade. Tecnologias de Assistência. Biblioteca Inclusiva. Necessidades especiais. Biblioteca Universitária.

\section{Introduction}

The constant struggle for the elimination of architectural barriers, the availability of adequate programs and actions, equipment, contents and information in alternative formats is part of the reality of people with special needs, regardless of the nation to which they belong. In the last decades, and mainly to the dissemination of the inclusive recent trends, these people are bringing into the educational institutions, as well as to libraries, new concerns and challenges (Seale et al., 2015).

In the last four decades it is possible to identify various initiatives and regulations $\mathbf{s}^{\mathbf{3}}$ that were created to support the process of inclusion of people with special needs, with the approval of legal documents and the formalization of different organizations that fight for the interests and rights of these people (Vieira, 2014). Despite these efforts there are still many difficulties, ranging from recognition to acceptance of these people by the society, being particularly relevant to give them access to education.

Indeed, the quest for an inclusive education system for people with special needs has been one of the major demands during the last decades, involving not only the right and access to education from regular to higher education, but also the right to fully participate in the society (Antunes; Faria, 2013). This leads us to identify the need of studying the university libraries scenario, namely in what regards how they are providing services to the academic community with special needs.

University libraries are important institutions in the current scenario of the Information and Communication Society, due to their scope and the role they play in the university context, in scientific, technological, cultural and social development (Bem et al., 2016). The access of people with special needs to higher education imposed a paradigm shift on university libraries, reaching different levels such as the generation and use of information to research activities carried out in higher education institutions (Bila, 2014).

The implementation of the processes of recognition and evaluation of degrees led universities to rethink their role, strengthening the need to plan, set goals and measure their results (Bem et al., 2016). The university libraries began to feel the importance of planning and evaluating the activities they carry out, especially those directed to the people with special needs. This trend is aligned to our belief that the inclusive university library should be an environment to welcome not only the person with special needs, but an accessible space for all, regardless of their limitations or any architectural barrier (Kirillova, 2015).

The environment of any space, as well as a library, has a huge impact on the experience and extent of a person's disability (Subramaniam, 2012). Inaccessible environments create barriers to participation and inclusion in different scenarios such as the ones in which a deaf user cannot have access to sign language interpreters, or a wheelchair user in a library building without accessible bathrooms or lifts, or a blind user that uses a library computer without a screen reading software.

\footnotetext{
3 International Year of People with Disabilities (1981); World Conference on Education for All (1990); Standards on Equalization of Opportunities for Persons with Disabilities (1993); International Meeting for the Discussion of Policies of Attendance for Persons with Special Educational Needs (1994); World Conference on Specific Educational Needs: Access and Quality (1994); Inter-American Convention on the Elimination of the Person with Disabilities (1999); Declaration of Caracas (2002); Declaration of Santo Domingo (2006); Decree-Law no. 163/2006, NBR9050/2015 of ABNT (Associação Brasileira de Normas Técnicas): Adequacy of Buildings and Equipment and Urban Furniture to the person with disabilities, National Policy for the Integration of Persons with Disabilities), among others.
} 
The university library environment may and should be changed to improve health, prevent or mitigate disabilities, and improve the quality of life for people with special needs. The changes may be implemented by complying with the legislation and public policies in order to develop inclusive approaches supported on the use of digital based solutions specially regarding: accessibility of the building and of the public urban transports (bus or coach) that allow people with physical handicaps or reduced mobility to reach the library; signaling on accessible conditions (namely using the international access symbol); and provision of accessible collections compatible with AT (Accessible Tools, head and mouth tips, reading boards with magnifying glass, autonomous readers, braille displays, audio books, among others).

For the World Health Organization the efficient planning and coordination of the services and products intended for these type of users depends on different dimensions expressly on the understanding of each scenario and of the specific needs of the disabled users (Organização das Nações Unidas, 2012).

In this context, we note that the knowledge and the attitudes of librarians are important factors affecting the planning and provision of services and products that the library may offer to students with special needs. Raising awareness and challenging the negative attitudes of librarians are the first steps towards creating more accessible libraries environments for users with special needs (Birdi; Wilson; Cocker, 2008).

Indeed, negative attitudes and behaviors of librarians have an adverse effect on users with special needs, generating negative consequences such as low self-esteem, less participation in university activities (both at learning and research levels), among others. In some cases, these users will no longer attend the library. On the other hand, stigma and discrimination may be countered, for example, through direct personal contact between librarians and these users and also through the social marketing of the library itself, that may have a very important role in disseminating the services and products aimed at these users. In this context, it is necessary the librarian may seeks specific skills qualifications, participating in projects and courses that allow his/her continued education and training on inclusion and accessibility.

The cohabitation of librarians with users with special needs should, therefore, be promoted in order to make these professional aware of the situation and to engage them in strategies that may enable them to better know about users with special needs.

It is, therefore, of utmost importance that these professionals may have the capacity to feel or imagine a situation experienced by students with special needs, seeking to understand their feelings and emotions, in a rational way, and attempting to feel what the other would feel. Empathy and altruism (Sampaio et al., 2009) are of most importance in this process and reinforce how relevant it is for the individuals to place themselves in the place or situation of the other to experience his/her experiences. This may lead people to help others by understanding the limitations, conditions and difficulties of the other (Bodaghi; Cheong; Zainab, 2016).

This paper is divided into four sections. Section one proposed a contextualization of the theme and presented the scope of work. Section two explains the methodological procedures used in this study. Section three presented the results and discussions structured in two subsections (directors profile and campus infrastructure). Finally, section four deals with the conclusions.

\section{Methodological Procedures}

This article reports partial and preliminary results of a more comprehensive research that aims to study the inclusive practices of university libraries in the Brazilian and Portuguese contexts and which includes a diagnostic stage of the experiences and cases (programs and projects) of AT use, being worth to mention the previous scarce studies carried out in Brazil and in Portugal on this matter (Neto, 2014; Vieira, 2014). 
The research contemplated a stage in which the directors of the Brazilian and Portuguese university libraries were inquired through the application of a survey, for that, an online questionnaire was applied to 87 directors (54 Brazilian and 33 Portuguese). Between December of 2015 to December of 2016 we obtained 50 valid answers, distributed by 28 Brazilian and 22 Portuguese libraries. The inclusion criteria for the sample was the library belonging to a federal university (in the Brazilian case) and the library belonging to a public university and/or a polytechnic institute (in the Portuguese case). Among the procedures carried out to launch the survey, the following should be highlighted: contact with library directors, preparation of the questionnaire, pre-testing/validation of the questionnaires and application of the survey to librarian directors.

The questionnaire is structured in different parts aiming to characterize: (i) library users; (ii) programs, projects and products on accessible solutions and AT; (iii) campus infrastructure (regarding accessibility in public parking, accessibility in public urban transport, internal tracks between buildings, sanitary and urban furniture on campus); and (iv) library infrastructure (for architectural accessibility, communicational accessibility, instrumental accessibility, methodological accessibility, programmatic accessibility). In this article we mainly present results related to the campus infrastructure.

Here we face problems regarding the return of the Terms of Consent of the Legal Responsible by Libraries, in many cases the investigation team had to send e-mails charging and making phone calls in return of the institutions. It should be mentioned that many of the directors of the university libraries refused to sign the consent form to participate in the investigation, justifying that their library did not develop any action, activity or strategy of accessibility and inclusion for users with disabilities.

Data was analysed using descriptive statistics, respecting the identification of the respondents and preserving the authenticity of the answers obtained.

\section{Results and Discussion}

The results and discussions are structured in two subsections (directors profile and campus infrastructure).

\section{Profile of library directors}

The 50 valid answers comprise 28 Brazilian libraries and 22 Portuguese ones. As shown in Table 1, the majority (28/50) of the directors of the libraries are Brazilians, followed by 22/50 Portuguese nationals.

Regarding the age group, gender, academic level and length of service, the highest indexes correspond to: 11/50 "41 to 50 years", 21/50 "Female", 9/50 "Specialization", 8/50 "11 a 20 years" and 7/50 "21 to 30 years", in the Portuguese case, and 13/50"+50 year", 22/50 "Female", 12/50 "Master" and 8/50 "Specialization", 11/50 "6 to 10 years",

4 in the Brazilian case.

These results are similar to other studies developed, as one developed in Sri Lanka (Wijayarathe; Amarasekara, 2015), where a predominance of professionals with similar age, gender, academic level and length of service was found, and in which a scenario of inexistence of good practices on accessibility and inclusion in library management was described.

\section{Campuses infrastructure}

Here, we will cover the items related to the category "Inclusive university: campus infrastructure", such as the "Architectural accessibility" subcategory. We will specify the conditions offered in the various campuses investigated in relation to the presence of urban public transport, public parking, accessibility in the areas of circulation between 
Table 1. Nationality, age group, gender, academic level and length of service.

\begin{tabular}{|c|c|c|c|c|c|c|c|}
\hline \multicolumn{5}{|c|}{ Age group (years) } & \multicolumn{3}{|c|}{ Gender } \\
\hline Nationality & 31 to 40 & 41 to 50 & +50 & Total & Female & Male & Total \\
\hline Brazilian & 10 & 5 & 13 & 28 & 22 & 6 & 28 \\
\hline Portuguese & 3 & 11 & 8 & 22 & 21 & 1 & 22 \\
\hline Total & 13 & 16 & 21 & 50 & 43 & 7 & 50 \\
\hline \multicolumn{8}{|c|}{ Academic level } \\
\hline Nationality & $\begin{array}{c}\text { Graduation/ } \\
\text { Degree }\end{array}$ & Specialization & & Master & Doctorate & Post-Doctorate & Total \\
\hline Brazilian & 1 & 8 & & 12 & 6 & 1 & 28 \\
\hline Portuguese & 3 & 9 & & 7 & 3 & 0 & 22 \\
\hline Total & 4 & 17 & & 19 & 9 & 1 & 50 \\
\hline \multicolumn{8}{|c|}{ Length of service (years) } \\
\hline Nationality & 1 to 5 & 6 to 10 & 11 to 20 & 21 to 30 & 31 to 40 & +40 & Total \\
\hline Brazilian & 1 & 11 & 2 & 9 & 5 & 0 & 28 \\
\hline Portuguese & 0 & 2 & 8 & 7 & 3 & 2 & 22 \\
\hline Total & 1 & 13 & 10 & 16 & 8 & 2 & 50 \\
\hline
\end{tabular}

Source: Elaborated by the authors (2017).

buildings and availability of accessible toilets and urban furniture. This is because talking about an inclusive university library requires verification of its surroundings, even because this information unit is part of a university, an organization that presents its peculiarities, social, economic and structural problems.

Thus, to understand our results in relation to the "Inclusive university: campus infrastructure" category, Chart 1 presents the Questions (Q) of the questionnaire that were analysed.

Regarding Q1, 11/28 respondents answered "yes", while 17/28 answered "no" in the context of Brazilian respondents. 12/22 of the Portuguese respondents stated "yes", 10/22 answered "no". Respondents who provided positive information, when encouraged to comment, made it clear that: "Considering that students circulate in the Campus using public transports - bus and metro -, it is deduced they comply with the legislation in force" or that "The Library is not integrated in a campus but in the center of the city, which means that the students use the metro and the bus"; "(There are) buses adapted for intercampus circulation". Regarding those respondents who gave negative information, the comments where:"I am not aware of the existence of this offer (on campus)", "The public transportation that circulates on campus and in the city is in poor condition and is not adapted (regarding accessibility)" and "The adapted buses are overcrowded and insufficient and the seats for pregnant women and the elderly are always taken".

This scenario is not unusual as reported in other studies that make evident that accessible public transportation in the surroundings of most universities still presents many problems; in the particular case of Brazil the situation is very precarious (Cavalcanti; Garcia; Rados, 2015).

Given the above, we understand it may not be possible to think of an urban environment without thinking about traffic quality and adapted for people with disabilities. Of course, in many countries, problems with traffic consequences are seen "both from the perspective of the environment as well as from public health, size is their impact on people's quality of life". This is so complex that "it implies for the traffic psychologist a formation committed to the study of cities and their urban planning, with public health, human conviviality and diversity" (Araújo et al., 2011, p.575). It is fundamental to plan public policies that may prioritize the traffic in the perspective of a "set of all 
Chart 1. Campus Infrastructure.

\begin{tabular}{|c|c|}
\hline \multicolumn{2}{|r|}{ Campus Infrastructure } \\
\hline No & Questions (Q) \\
\hline Q1 & $\begin{array}{l}\text { Does the Campus have public transport lines (bus or bus) adapted for the transport of people with physical disabilities or reduced } \\
\text { mobility, according to NBR 14022/2011 (BR) or Decree-Law n¹63/2006 (PT)? }\end{array}$ \\
\hline Q2 & $\begin{array}{l}\text { Is there a route between boarding/landing public buses to the entrance of the library free of obstacles (steps, concrete blocks/ } \\
\text { cement, grills or spare iron bars on the floor)? }\end{array}$ \\
\hline Q3 & Does the Campus offer parking with preferential places for people with physical disabilities or reduced mobility? \\
\hline Q4 & Does the library have a parking lot with preferential spaces for people with physical disabilities or reduced mobility? \\
\hline Q5 & $\begin{array}{l}\text { If the car park has } 11 \text { to } 100 \text { places, are at least three of the spaces preferred for people with physical limitations or reduced mobility? } \\
\text { (For a parking of up to } 10 \text { places, there is no legal provision, however, it is recommended to reserve at least one preferred place)? }\end{array}$ \\
\hline Q6 & If the car park has more than 100 places, at least $1 \%$ of the places is preferred for people with physical disabilities or reduced mobility? \\
\hline Q7 & $\begin{array}{l}\text { Do the preferred places for people with physical limitations or reduced mobility have horizontal (painted on the floor) and vertical } \\
\text { sign using the international access symbol? (It is also recommended that the place may present a written sign with the information } \\
\text { regarding the reservation status of the place and the target public). }\end{array}$ \\
\hline Q8 & Are the preferential places located on a flat floor? \\
\hline Q9 & $\begin{array}{l}\text { Do the preferential places have an additional traffic space of at least } 1,00 \mathrm{~m} \text { to } 1,20 \mathrm{~m} \text { wide when away from the pedestrian crosswalk, } \\
\text { in order to avoid the movement of people with physical disabilities or reduced mobility between vehicles? }\end{array}$ \\
\hline Q10 & $\begin{array}{l}\text { Are preferential places connected to the lowering part of the sidewalk and/or ramp to facilitate the access of people in wheelchairs } \\
\text { and/or people with locomotion difficulty? }\end{array}$ \\
\hline Q11 & $\begin{array}{l}\text { Are preferred places connected to an accessible track that connects to the library or building in which it is located, free of obstacles } \\
\text { such as steps, concrete blocks, grills, or spare iron bars on the floor? (It is recommended that preferred places may be as close as } \\
\text { possible to the main entrance or optional accessible track of the library). }\end{array}$ \\
\hline Q12 & $\begin{array}{l}\text { If it's not possible to have an accessible track between the parking lot and the accessible entrances of the library, are there parking } \\
\text { spaces exclusively for people with physical limitations or reduced mobility connected to the entrances through accessible tracks? }\end{array}$ \\
\hline Q13 & Does the path between the buildings and the library have steps? \\
\hline Q14 & Does the path between the buildings and the library have ramps? \\
\hline Q15 & If there is a ramp, is the slope measured in accordance with NBR 9050/2015 (BR) or Decree-Law no 163/2006 (PT)? \\
\hline Q16 & Is the minimum ramp width between buildings $1.20 \mathrm{~m}$ to $1.50 \mathrm{~m}$ (Decree-Law n¹63/2006 or NBR 9050/2015)? \\
\hline Q17 & Are there handrails on both sides of the ramp? \\
\hline
\end{tabular}

Source: Elaborated by the authors (2017).

the daily commutes, made by the sidewalks and roads of the city, and that appears in the street in the form of the general movement of pedestrians and vehicles" (Vasconcelos, 1985, p.11).

We may correlate traffic and its problems with the concept of symbolic violence in Bourdieu's discourse. Therefore, in this perspective, traffic and its variants (urban transport, road or circulation environment etc.) are part of a power struggle between social classes. This dispute concerns competition for physical space, time and access to urban equipment. It represents a permanent, collective and conflicting negotiation of space. Quarrels that arise from conflicts of interest between social groups. As for the ideological point of view, it corresponds to "... the position that people assign and occupy in society [which] will condition their dispute over space through the election and use of certain means of transport ..." (Vasconcelos, 1985, p.34). Such a dispute over space enables and creates physical conflict, which will lead to a "... negotiation of this space guided by the real or imaginary power of each social actor involved ..." (Vasconcelos, 1985, p.34).

In this case, the imaginary power corresponds to the value of the symbolic power of capacity and type attributed to vehicles, where the greater, faster, more potent the vehicle, including the fact that it is a private vehicle 
and a public vehicle, the greater its supremacy and symbolic status in a dispute. The circulation space corresponds to consumption, which includes the type of transportation and its quality, reflecting different social and economic conditions between families and people. This leads to several treatment differences depending on the location and purchasing power of the actors (Araújo et al., 2011).

For Q2, the following distribution of responses was obtained: in the Brazilian context, 10/28 answered "yes" and 18/28 answered "no" while. In the Portuguese case, 17/22 responded "yes" and 5/22 responded that "no".

Indeed, there are still various infrastructural and architectural problems in the daily activities of the disabled people, especially when they need to use public transportation, revealing that major social and attitudinal problems remain to be solved in our society, that hinder disabled citizens to have an autonomous and self-sufficient life (Cavalcanti; Garcia; Rados, 2015).

In the Brazilian case, and according to our results, students with special needs that use urban public transports have different obstacles to overcome, namely regarding the boarding/landing of the bus, as many architectural barriers were reported near the buildings where libraries are installed (like stairs and sidewalks without lowering the curb, making it impossible to use an accessible route).

Seco, Gonçalves, and Costa $(2008$, p.8) point out that the cause of noncompliance with the law generally stems from the effect of the existence of a deficient supply of parking, which causes, among other things, the illegal parking of non-authorized people in space destined for vehicles of people with disabilities. Thus, they highlight some factors that may influence the level of (dis)compliance of the parking standards: "visibility and readability of the marks and traffic signals; physical restrictions on parking; perception of the effects of non-compliance with the rules; rationality of regulation; [...] reason for the trip; duration of the infringement; and awareness of the place". In the case of university parking lots, stronger measures could be used as alternatives, for example, we suggested the privatization of parking, even at symbolic prices, which could establish a more energetic control over compliance with rules, as already occurs in some campuses universities in Europe.

In response to Q3 (campus parking with preferential places for people with physical disabilities or reduced mobility), 23/28 of the Brazilian respondents answered "yes" and 3/28 answered "no" (2/28 didn't answer); in the Portuguese case, 16/22 responded "yes", 4/22 responded "no" (2/22 didn't answer).

Results show that both countries campuses offer preferential vacancies to people with physical disabilities or reduced mobility. Nevertheless, there are still many cases of non-compliance with regulations on this matter and a lack of respect for people with disabilities. Some respondents, when commenting on their positive responses, made it clear that: "...these preferential places are not always respected" and many times "people usually park on ramps and lowered sidewalks, when they have them, and do not respect pedestrians".

Thus, the lack of preferential places for people with physical handicap or reduced mobility in library parking places entails a number of difficulties for users with physical or motor limitations, since they are forced to move to parking lots farther from the library and thus, face longer courses and, possibly, more obstacles.

As for Q4 (library parking with preferential vacancies for people with physical disabilities or reduced mobility), 17/28 of the Brazilian respondents answered "yes", 9/28 answered "no" (2/28 didn't answer). In the Portuguese case, 7/22 responded "yes", 14/22 responded "no" (1/22 didn't answer).

These results raise our attention to the Portuguese context being interesting to analyze the respondents comments, such as: "The libraries do not have their own parking", "After the renovation made around the library, the preferred parking is over, but we are working to make it come back", "The Library does not have a car park" and "The library does not have its own parking lot".

The lack of preferential places for people with physical disabilities or reduced mobility in library parking places entails a number of difficulties for users with motor handicaps as they are forced to park farther from the library and thus face longer tracks, possibly with more obstacles. 
For Q5 (special parking places for people with physical limitations or reduced mobility), 15/28 of the Brazilian respondents answered "yes" and 8/28 answered "no"(2/28 didn't answer); in the Portuguese context, 5/22 responded "yes" and 15/22 responded "no" (2/22 didn't answer).

With regard to Q6 (1\% of the parking places for people with physical disabilities or reduced mobility), we found that the Brazilian context, 13/28 respondents answered "yes" and 10/28 answered "no" (5/28 didn't answer). In the Portuguese context, 7/22 responded "yes" and 13/22 responded "no" (2/22 didn't answer).

The answers found for Q5 and Q6 show the non-compliance with the legislation that regulates the right to statelessness for people with physical disabilities or reduced mobility. In addition to calling attention of the university administrators to this lack that may lead to irreparable damages.

As for Q7 (preferred places with vertical sign using the international access symbol), and considering the Brazilian context, 15/28 respondents answered "yes" and 8/28 responded "no" (5/28 didn't answer); 7/22 of the Portuguese respondents answered "yes", 9/22 responded "no" (6/22 didn't answer).

Those respondents who answered "yes", in both countries, commented that the signaling is only horizontal and that the parking has a lack of vertical signs. This reality has also been identified by Corrêa (2014) in a study developed in a higher education setting that revealed not only the lack of vertical and horizontal signs in the parking lots, but also that the signs indicating the direction of sectors had inadequate lighting in the inner streets of the campus.

Considering Q8 (preferential places located on a flat floor) 15/28 of the Brazilian respondents answered "yes", 11/28 responded "no" (2/28 didn't answer); 5/22 of the Portuguese respondents answered "yes", 16/22 replied "no" and $1 / 22$ didn't answer.

Respondents who answered "no", in the Brazilian context, commented on their response, stating that: "Floors are irregular, often causing damages to vehicles, especially in the winter period after rainfall. Water puddles are also a problem for wheelchairs users and for visually impaired students".

According to the study conducted by Corrêa (2014), these situations are usual in parking lots of Brazilian universities, which in most cases have inadequately constructed floors, making it impossible to access sidewalks or walkways, especially for people who use wheelchairs or other special equipment to get around.

As for Q9 (additional traffic space from the pedestrian crosswalk), 12/28 of the Brazilian respondents answered "yes" and 12/28 responded "no" (4/28 didn't answer). In the Portuguese case, 9/22 answered "yes" and 10/22 responded "no" (3/22 didn't answer). In both countries the gathered data of the "no" and "no answer" corresponds to half of the respondents.

In general, some of these respondents commenting on their answers have shown that the library is located on a campus with historic architectural features, and predominantly the path between the buildings has slopes and steps. It should be noted that the data make evident the existence of steps that within the framework of the 8 architectural barriers may be considered as obstacles or obstructions that may impede the access or freedom of movement or safe movement for people with disabilities (Silva; Lima, 2016).

Regarding Q10 (preferential places connected to the lowering of the sidewalk and/or ramp), 19/28 of the Brazilian respondents answered "yes" and 7/28 answered "no" (2/28 didn't answer). In the Portuguese scenario, 8/22 responded "yes" and 12/22 responded "no" (2/22 didn't answer).

This asymmetry between the Brazilian and the Portuguese context is lined with the results obtained by Emmanuelli (2009), which depict a positive scenario in the Brazilian reality.

As for Q11 (preferred places connected to an accessible route that connects to the library), 8/28 of the Brazilian respondents answered "yes" and 18/28 answered "no" (2/28 didn't answer). 10/22 of the Portuguese ones answered "yes" and 11/22 replied "no" (11/22 didn't answer). 
These results show that the preferential places are not connected to an accessible track that enables users to reach the library, with no obstacles such as steps, concrete blocks, grids or spare iron bars on the floor. This scenario illustrates how difficult it may be for students who use wheelchairs or have reduced mobility to access the library services. Indeed, any library should have an accessible and free of any obstacles track. Our results show that there are many obstacles that interfere to the access of most of the libraries studied.

In response to Q12 (parking spaces exclusively for people with physical limitations or reduced mobility connected to the entrances through accessible tracks), 6/28 Brazilian respondents answered "yes" and 19/28 responded "no" (3/28 didn't answer). As for the Portuguese respondents, 3/22 answered "yes" and 18/22 replied "no" (1/22 didn't answer). Respondents of both countries who answered "no" commented on their answers stating that "The library does not have its own parking lot".

These results show that there are not many accessible tracks or parking with spaces for people with physical disabilities or reduced mobility, a scenario that conditions the accessibility of the libraries investigated.

As for Q13 (steps in the path between the buildings and the library), 15/28 of the Brazilian respondents answered "yes" and 10/28 responded "no" (3/28 didn't answer). In what regards the Portuguese respondents, 11/22 answered "yes" and 10/22 responded "no" (1/22 didn't answer).

Respondents who answered "yes" in the Brazilian context, commenting on their answers, said: "Sometimes the pavement is very irregular and has few steps", "The buildings on the campus where the library is located are old, with little space between them, not allowing the construction of accessible ramps", "(the building) has steps and ramp with handrail" and "the main entrance has stairs, but there are two more entrances that have ramps".

Portuguese respondents who answered "yes" commented that "The main entrance of the building has steps but there are also access ramps", "[yes] but there is a lateral access ramp to the main door of the library" and "yes, but there are some alternative tracks with ramps and elevator".

As Silva and Lima (2016) state, a path with steps between buildings and the libraries may be considered a barrier to the library accessibility, conditioning the freedom of movement and the safety for people with special needs.

In Q14 (ramps in the path between the buildings and the library), 12/28 of the Brazilian respondents answered "yes" and 14/28 answered "no" (2/28 didn't answer). 9/22 of the Portuguese respondents answered "yes" and 12/22 answered "no" (1/22 didn't answer).

Respondents who answered "yes" in the Brazilian context commented: "Sometimes the floor ramps' are very irregular and have few stairs", "The buildings on the campus where the library is located are old, with little space between them, not allowing the construction of accessible ramps" and "the main entrance has steps, but there are two more entrances that have ramps". Portuguese respondents who answered "yes" said: "The main entrance of the building has steps but there are also access ramps", "yes, but there is a side ramp on the main entrance of the library" and "yes, but there are some alternative tracks with ramps and lift".

In response to Q15 (slope ramp in accordance with regulations) 4/28 of the Brazilian respondents answered "yes" and 20/28 responded "no" (4/22 didn't answer). 3/22 of the Portuguese respondents responded "yes" 15/22 responded "no" (4/22 didn't answer).

The Brazilian respondents who answered "no", commenting on their responses, said: "I cannot inform" and "There are no access ramps to the building". In the case of Portuguese respondents who answered "no", commenting on their answers, they said:"I do not know the measure of the inclination", "We do not have information that allows us to give a reasoned answer" and "We do not have this information".

In view of the comments, one may say that the respondents do not have detailed information about the slope of the ramps. Perhaps this lack of knowledge is the cause of the high index of the "no" answers. 
Regarding Q16 (minimum ramp width between buildings according to regulations), 5/28 of the Brazilian respondents answered "yes" and 19/28 answered "no" (4/28 didn't answer). 8/22 of the Portuguese respondents responded "yes" and 11/22 "no" (3/22 didn't answer).

The Brazilian respondents who answered "no", commenting on their answers said: "I would not know how to respond" and "There are no ramps". In the case of Portuguese respondents who answered "no", commenting on their answers, they said: "We do not have information that allows us to give a reasoned answer" and "We do not have this information".

As in Q15, these comments show that respondents do not have accurate information that enables them to indicate whether the minimum ramp width between buildings complies with the current legislation.

In response to Q17 (handrails on both sides of the ramp), 9/28 Brazilian respondents answered "yes" and 15/28 responded "no" (4/28 didn't answer). 2/22 of the Portuguese ones answered "yes" and 16/22 responded "no" (4/22 didn't answer).

Both of the Brazilian and Portuguese respondents who answered "no" commented in line with the above mentioned comments that were given to Q15 and Q16, which depicts a scenario of low knowledge on the current regulations concerning architectural accessibility. There are still many challenges to be faced by librarians in this matter in order to enable them to better understand the requirements for an inclusive and accessible university library.

In light of the above, it is worth noting that we are dealing with a theme that, in spite of many studies already developed, still needs to be much more explored and discussed by society, in order to generate public policies or affirmative actions aimed at ensuring respect, resilience, empowerment and quality of life for university students with disabilities. This change begins with the creation of public policies aimed at favoring access to higher education and the provision of university services so that these students may remain and complete their studies.

But talking about higher education and inclusion policies for students with disabilities in Brazil and Portugal we must first of all assume that whatever the evolution of the context - both global and national - there is hardly an equal path, (social, economic, cultural and political) presented by each scenario that will influence the entire evolutionary path (Martins; Vale; Barbosa, 2015).

This is justified because different nations have different rhythms and intensities of implementing educational policies or redefining the working environment of higher education institutions to promote the inclusion of students with disabilities or some type of limitation.

We emphasize that the greatest challenge of all nations is to incorporate the social model of disability in all its policies and programs, prioritizing the equality of conditions and rights, as a priority, to education.

Comparing to Brazil, in Portugal the quantitative of legislation for people with disabilities presents a much smaller collection. However, both countries need to advance further in institutional policies and much more in actions of good practices by their higher education institutions. Emphasizing that the lack of these actions will culminate in welfare practices of integration, not inclusion. Thus, it is important to emphasize that higher education is one of the pillars of human rights for the accomplishment of democracy, sustainable development and peace. It should therefore be accessible to all, indiscriminately.

Thus, the data presented here show similar realities, or show the differences between the two countries studied. Overall, there is a clear lack of knowledge about the various dimensions of accessibility addressed by Sassaki (2005).

\section{Conclusion}

The results presented in this paper allowed us to better understand how Brazilian (federal) and Portuguese public university libraries are developing inclusive programs and supporting users with special needs. In particular, 
we concluded that, although the professionals of these libraries have been investing in their continuous training and education, "accessibility" and "inclusion" are not topics in which they seem to have expertise, which calls for the need of offering specific training in this field, specifically adjusted to the profile of librarians.

Our results also show that the campuses'infrastructure has different accessibility problems, namely regarding public parking, public transports, and paths between buildings. The architectural accessibility of the analyzed campuses may be characterized as being quite fragile, although some exceptions have been identified.

Despite this scenario, respondents (libraries directors) seem to be aware of their weaknesses and show openness to change in order to build future solutions to improve the accessibility and inclusion of the libraries.

In this scenario, we recommend the universities to review their accessibility policies, especially regarding the possibility of having public transportation, on campus, with adaptable resources. As for university libraries, they should prioritize the ongoing training of their librarian teams in the areas of accessibility, inclusion, and inclusive planning, being this not only an institutional demand, but also an individual attitude that must be adopted by all the libraries' professionals.

In a nutshell, the results described in this paper demonstrate that there are still some fragilities on these libraries' inclusive nature, especially in what concerns their architectural options and its impact on the promotion of the inclusion of users with special needs.

\section{Acknowledgments}

To the collaboration of the teachers Vera Giust and Anamaria Mesquita Souza for the grammatical revisions of Portuguese and Brazilian languages.

\section{Contributors}

All three authors contributed substantially to the design, analysis and interpretation of the data, review and approval of the final version of the article.

\section{References}

Antunes, A.; Faria, C. A universidade e a pessoa com necessidades especiais: estudo qualitativo sobre perceções de mudança social, institucional e pessoal. Indagatio Didactica, v.5, n.2, p.474-488, 2013. Disponível em: <http:// revistas.ua.pt/index.php/ID/article/view/2467>. Acesso em: 22 mar. 2017.

Araújo, M.R.M. et al. Transporte público coletivo: discutindo acessibilidade, mobilidade e qualidade de vida. Psicologia e Sociedade, v.3, n.3, p.574-582, 2011. http://dx.doi.org/10.1590/ S0102-71822011000300015

Bem, R.M. et al. Avaliação de bibliotecas universitárias: normas e padrões. Pesquisa Brasileira em Ciência da Informação e Biblioteconomia, v.11, n.1, p.100-116, 2016.

Bila, A.S.A. Biblioteca de arte inclusiva: informação e conhecimento acessíveis aos leitores com deficiência visual. 2014. 86f. Relatório (Mestrado em Ciência da Informação e Educação) - Universidade Nova de Lisboa, Lisboa, 2014. Disponível em: <http://hdl.handle.net/10362/14767>. Acesso em: 22 mar. 2017.
Birdi, B., Wilson, K., Cocker, J. The public library, exclusion and empathy: A literature review. Library Review, v.8, n.57, p.576-592, 2008. http://dx.doi.org/10.1108/00242530810899568

Bodaghi, N.B.; Cheong, L.S.; Zainab, A.N. Librarians empathy: Visually impaired students' experiences towards inclusion and sense of belonging in an academic library. Journal of Academic Librarianship, v.42, n.1, p.87-96, 2016. http://dx.doi. org/10.1016/j.acalib.2015.11.003

Cavalcanti, C.O.P.; Garcia, R.I.; Rados, G.J.V. Acessibilidade física na biblioteca do Instituto Federal de Educação, Ciência e Tecnologia de Santa Catarina. Revista ACB: Biblioteconomia em Santa Catarina, v.3, n.48, p.483-499, 2015.

Corrêa, P.M. Acessibilidade no ensino superior: instrumento para avaliação, satisfação dos alunos com deficiência e percepção de coordenadores de cursos. 2014. 283f. Tese (Doutorado em Educação) - Universidade Estadual Paulista Júlio de Mesquita Filho, Marília, 2014. Disponível em: <https://www.marilia. unesp.br/Home/Pos-Graduacao/Educacao/Dissertacoes/ correa_pm_do_mar.pdf>. Acesso em: 22 mar. 2017. 
Emmanuelli, M.N. Acessibilidade física em bibliotecas universitárias: um direito de todos. 2009. 83f. Dissertação (Especialização em Gestão de Bibliotecas Universitárias) - Universidade Federal do Rio Grande do Sul, Porto Alegre, 2009. Disponível em: <https://www.lume.ufrgs.br/bitstream/handle/ 10183/18490/000730119.pdf? sequence=1 >. Acesso em: 22 mar. 2017.

Kirillova, E.A. Historical and theoretical bases of inclusive education development in Russia. Review of European Studies, v.7, n.5, p.31-37, 2015. http://dx.doi.org/10.5539/res.v7n5p31

Martins, D.M.; Vale, A.A.; Barbosa, T. Políticas de expansão da educação superior no Brasil. Revista Brasileira de Educação, v.20, n.60, p.31-50, 2015. http://dx.doi.org/10.1590/S1413-24 782015206003

Neto, L.M.F.P. O papel social da biblioteca universitária na inclusão do indivíduo portador de deficiência visual. Cadernos Bad, v.1, p.19-31, 2014. Disponível em: <ww.bad.pt/ publicacoes/index.php/cadernos/article/view/1046>. Acesso em: 7 abr. 2016.

Organização das Nações Unidas. Relatório mundial sobre a deficiência. São Paulo: Secretaria de Direitos da Pessoa com Deficiência, 2012. Disponível em: <http://www. pessoacomdeficiencia.sp.gov.br/usr/share/documents/ RELATORIO_MUNDIAL_COMPLETO.pdf>. Acesso em: 22 set. 2017.

Sampaio, L.R. et al. A. Revisão de aspectos conceituais, teóricos e metodológicos da empatia. Psicologia: Ciência e Profissão, v.29, n.2, p.212-227, 2009. http://dx.doi.org/10.1590/S1414-98 932009000200002

Sassaki, R.K. Inclusão: o paradigma do século XXI. Inclusão: Revista de Educação Especial, 2005. Disponível em: <http:// portal.mec.gov.br/seesp/arquivos/pdf/revistainclusao1.pdf>. Acesso em: 7 abr. 2015.
Seco, Á.J.M.; Gonçalves, J.H.G.; Costa, A.H.P. Manual do planeamento de acessibilidade e transporte: engenharia de tráfego: conceitos básicos. Comissão de Coordenação e Desenvolvimento Regional do Norte, 2008. p.8. Disponível em: <http://norteemrede.ccdr-n.pt/planeamento/publicacoes/ mpagv/01EngTrafego.pdf>. Acesso em: 7 abr. 2016.

Seale, J. et al. Not the right kind of "digital capital"? An examination of the complex relationship between disabled students, their technologies and higher education institutions. Computers and Education, v.82, p.118-128, 2015. http://dx.doi. org/10.1016/j.compedu.2014.11.007

Silva, E.; Lima, I.F. Acessibilidade em unidades de informação e cultura: um estudo na fundação espaço cultural da Paraíba (FUNESC). Biblionline, v.12, n.3, p.79-93, 2016.

Subramaniam, M. The implications of a decade of diversityrelated doctoral dissertations (2000-2009) in LIS: Supporting inclusive library practices. Library Quarterly, v.82, n.3, p.361-377, 2012.

Vasconcelos, E.A. O que é trânsito. São Paulo: Brasiliense, 1985. p.34.

Vieira, L.C.B. Biblioteca inclusiva: repensando políticas de acesso e inclusão para deficientes auditivos na Universidade Federal do Maranhão. Biblionline, v.10, n.1, p.82-101, 2014. Disponível em: <http://periodicos.ufpb.br/ojs/index.php/ biblio/article/view/17882/11099>. Acesso em: 7 abr. 2016.

Wijayaratne, A.; Amarasekara, R. Librarians' competency and willingness towards serving the users with disabilities: Where do Sri Lankan librarians stand? Journal of the University Librarians Association of Sri Lanka, v.18, n.1, p.1-18, 2015. http:// dx.doi.org/10.4038/jula.v18i1.7858 